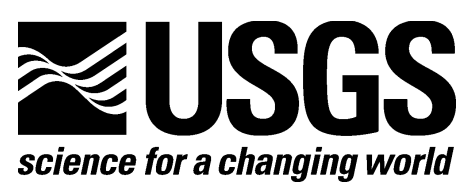

\title{
Terrigenous Sediment Provenance from Geochemical Tracers, South Molokai Reef Flat, Hawaii
}

By Renee K. Takesue

Open-File Report 2010-1155

U.S. Department of the Interior U.S. Geological Survey 


\section{U.S. Department of the Interior \\ KEN SALAZAR, Secretary}

\section{U.S. Geological Survey \\ Marcia K. McNutt, Director}

U.S. Geological Survey, Reston, Virginia: 2010

For product and ordering information:

World Wide Web: http://www.usgs.gov/pubprod

Telephone: 1-888-ASK-USGS

For more information on the USGS-the Federal source for science about the Earth,

its natural and living resources, natural hazards, and the environment:

World Wide Web: http://www.usgs.gov

Telephone: 1-888-ASK-USGS

Suggested citation:

Takesue, R.K., 2010, Terrigenous sediment provenance from geochemical tracers, south Molokai reef flat, Hawaii: U.S. Geological Survey Open-File Report 2010-1155, 17 p.

[http://pubs.usgs.gov/of/2010/1155].

Any use of trade, product, or firm names is for descriptive purposes only and does not imply endorsement by the U.S. Government.

Although this report is in the public domain, permission must be secured from the individual copyright owners to reproduce any copyrighted material contained within this report. 


\section{Contents}

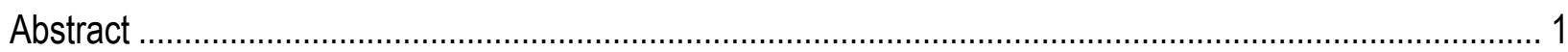

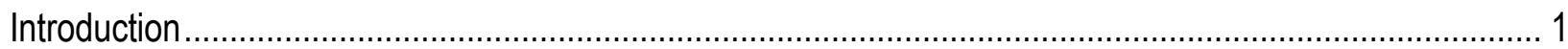

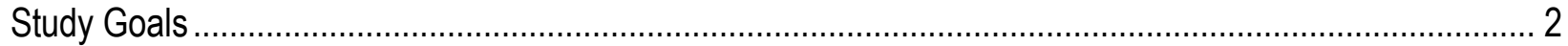

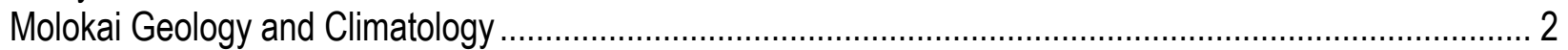

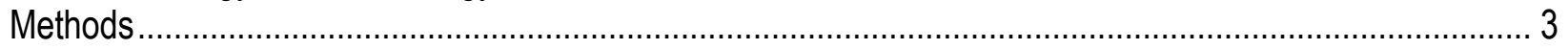

Sediment and Rock Collection................................................................................................. 3

Upland Sediment and Basalt....................................................................................... 3

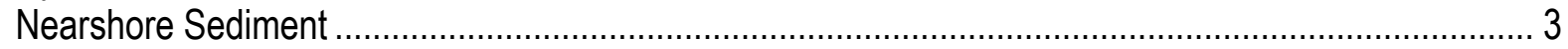

Sediment Processing ............................................................................................................. 3

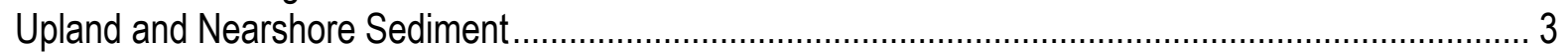

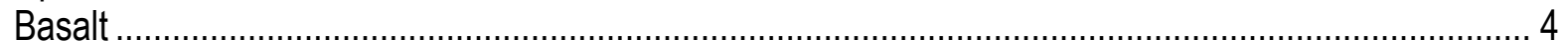

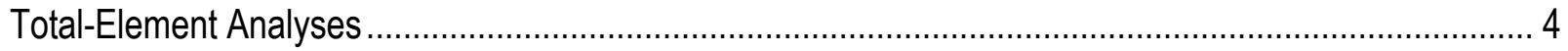

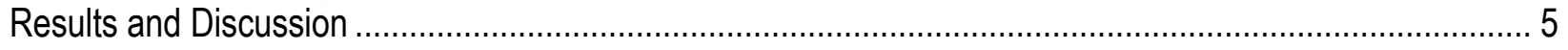

Gulch and Hillside Basalt Compositions ……............................................................................. 5

Elements Associated with Marine Sources.................................................................................. 5

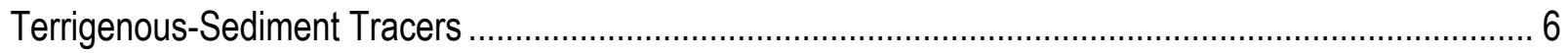

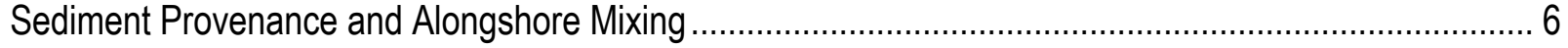

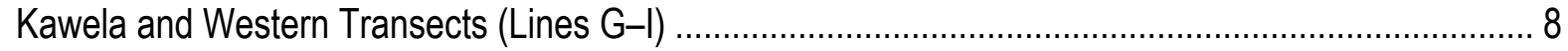

Kamalo and the Eastern Transect (Line A) ……………….................................................... 9

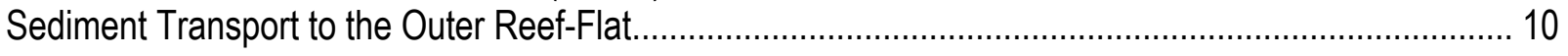

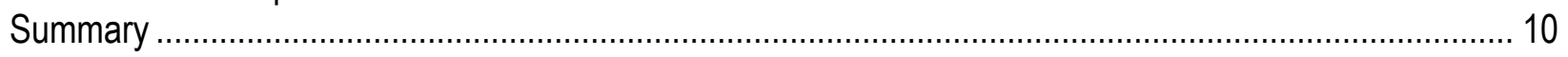

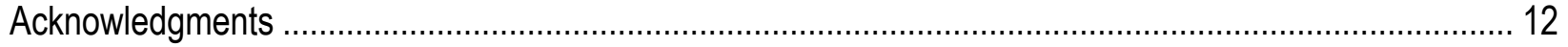

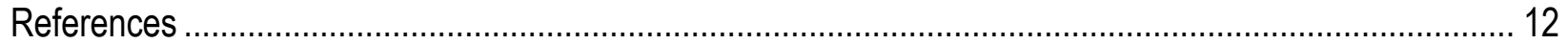




\section{Figures}

Figure 1. Map of Molokai and reef-flat transects designated by letters. Letter size shows transect length. Insets show the location of Molokai in the Hawaiian island chain, and upland sampling locations in Kawela and Kamalo watersheds. Filled circles are basalt; open circles are stream sediment.

Figure 2. Variations of sediment composition along cross-shore transects as a function of distance from shore, Molokai reef-flat, Hawaii. A, Ca; B, Al; and C, Fe.

Figure 3. Comparisons of elemental compositions of basalt, upland sediment, and nearshore sediment, Molokai, Hawaii. A, Sr versus $\mathrm{Ca}, \mathrm{B}, \mathrm{Cr}$ versus $\mathrm{Fe}, \mathrm{C}$, Ti versus $\mathrm{Fe}$, and D, Ba versus Al. BA is basalt; KA is Kawela; KO is Kamalo; NS is nearshore.

Figure 4. Comparison of $\mathrm{Cu}$ to Fe contents of basalt, upland sediment, and nearshore sediment, Molokai, Hawaii. Lines are least-squares regression lines. highway is sediment sampled just below the highway bridge over Kamalo Stream, upstr is sediment sampled 2 $\mathrm{km}$ upstream of Kamalo mouth. BA is basalt; KA is Kawela; KO is Kamalo; NS is nearshore.

Figure 5. Comparisons of $\mathrm{Cd} / \mathrm{Th}$ and $\mathrm{Co} / \mathrm{Th}$ ratios in basalt, upland sediment, and nearshore sediment, Molokai, Hawaii. The line in each plot is a compositional mixing line between alkalic and tholeiitic basalt. Labels show transect (letter) and distance from shore (number) of nearshore sites with elevated $\mathrm{Cd} / \mathrm{Th}$ ratios. BA is basalt; KA is Kawela; KO is Kamalo; NS is nearshore.

\section{Tables}

Table 1. Locations of nearshore sediment used for geochemical analyses, Molokai reef-flat, Hawaii.

Table 2. Major-, trace-, and rare-earth element contents of Kawela basalt, Molokai reef-flat, Hawaii

\section{Appendixes}

Appendix 1. Major-element compositions of basalt, upland sediment, and nearshore sediment, Molokai, Hawaii.

Appendix 2. Trace-element compositions of basalt, upland sediment, and nearshore sediment, Molokai, Hawaii. 


\title{
Terrigenous Sediment Provenance from Geochemical Tracers, South Molokai Reef Flat, Hawaii
}

\author{
By Renee K. Takesue
}

\begin{abstract}
Land-derived runoff is one of the greatest threats to coral-reef health. Identification of runoff sources is an important step in erosion mitigation efforts. A geochemical sediment provenance study was done in uplands and across the adjacent fringing reef on the southeast shore of Molokai, Hawaii, to determine whether sediment runoff originated from hillsides or gulches. Source-region identification was based on geochemical differences between alkalic basalt, which outcrops on hillsides, and tholeiitic basalt, which outcrops in gulches. In Kawela watershed, copper to iron ratios $(\mathrm{Cu} / \mathrm{Fe})$ were distinct in hillside soil versus gulch sediment and suggest that hillside erosion is the predominant mechanism of sediment delivery to the nearshore. This suggests that runoff-mitigation efforts should take steps to reduce hillside erosion. Cadmium to thorium ratios $(\mathrm{Cd} / \mathrm{Th})$ in nearshore sediment suggest that there is a high-Cd source of runoff east of Kamalo Gulch. This compositional difference is consistent with the predominance of tholeiitic basalt on the eastern end of Molokai.
\end{abstract}

\section{Introduction}

Large-scale vegetation removal and alteration of the land surface has increased sediment erosion and runoff to the south coast of Molokai and appears to have impacted the fringing coral reef (Jokiel and others, 2008). Since European settlement in the 1770s, the land has been logged and used for ranching and commercial agriculture (Roberts and Field, 2008); however, commercial activities do not appear to have resulted in heavy-metal pollution of Molokai soil (Bothner and others, 2006; Carr and Nipper, 2008). As industry and human populations declined, feral grazers (goats, pigs, deer) proliferated, preventing re-establishment of hillside vegetation. The loss of hillside vegetation has resulted in increased sediment runoff which, coupled with man-made impediments to alongshore flow (fishponds, the 800-m-long Kaunakakai pier), has altered nearshore sediment dynamics and increased water-column turbidity along the southsoutheast coast of Molokai (Ogston and others, 2004; Presto and others, 2006; Ogston and others, 2008). Turbid water appears to have taken a toll on coral and their symbionts, as live coral cover declines dramatically from 80-100 percent to 0-20 percent offshore of Kawela Stream mouth (Jokiel and others, 2008; Bothner and others, 2006), south Molokai's largest point of surface runoff (Tribble and Oki, 2008). Identification of watersheds or regions of watersheds prone to soil erosion and runoff could help mitigation efforts target problematic areas. 


\section{Study Goals}

The goals of this study were to identify geochemical tracers of terrigenous runoff (landderived soil and sediment) in sediment deposited on the eastern half of the south Molokai reef (corresponding to the region between Kamalo and Kaunakakai) and to explore whether sediment in separate watersheds or regions of watersheds had distinct geochemical signatures that would allow identification, or fingerprinting, of different sources of terrigenous runoff.

\section{Molokai Geology and Climatology}

The island of Molokai formed when two tholeiitic basalt shield volcanoes, Mauna Kea and Wailau, coalesced 1.7 - 1.9 million years ago (Ma) (Stearns and MacDonald, 1947). The two volcanoes give the island a rectangular shape with the long axis oriented east to west (fig. 1). Post-shield eruptions at 1.5 Ma and 1.8 Ma capped Mauna Kea and Wailau with a 15-150 m thick layer of alkalic basalt (Stearns and MacDonald, 1947). Alkalic basalt forms surficial deposits on hillsides of Kawela watershed and is the dominant rock type along the coastal plain between the mouths of Kamalo and Kawela streams (Oki, 1997). Tholeiitic basalt is exposed in gulches and is the dominant rock type along the coastal plain from the mouth of Kawela stream west to the town of Kaunakakai (Oki, 1997). Geochemical differences between alkalic and tholeiitic basalt (Stearns and MacDonald, 1947; Beeson, 1976; Clague and Beeson, 1980) might make it possible to distinguish soil weathered from alkalic basalt on hillsides versus sediment originating from tholeiitic basalt in gulches. Because alkalic basalts are derived from a depleted magma chamber, they are enriched in mantle-incompatible alkaline, alkaline earth, and rare-earth elements (Taylor and McLennan, 1985).

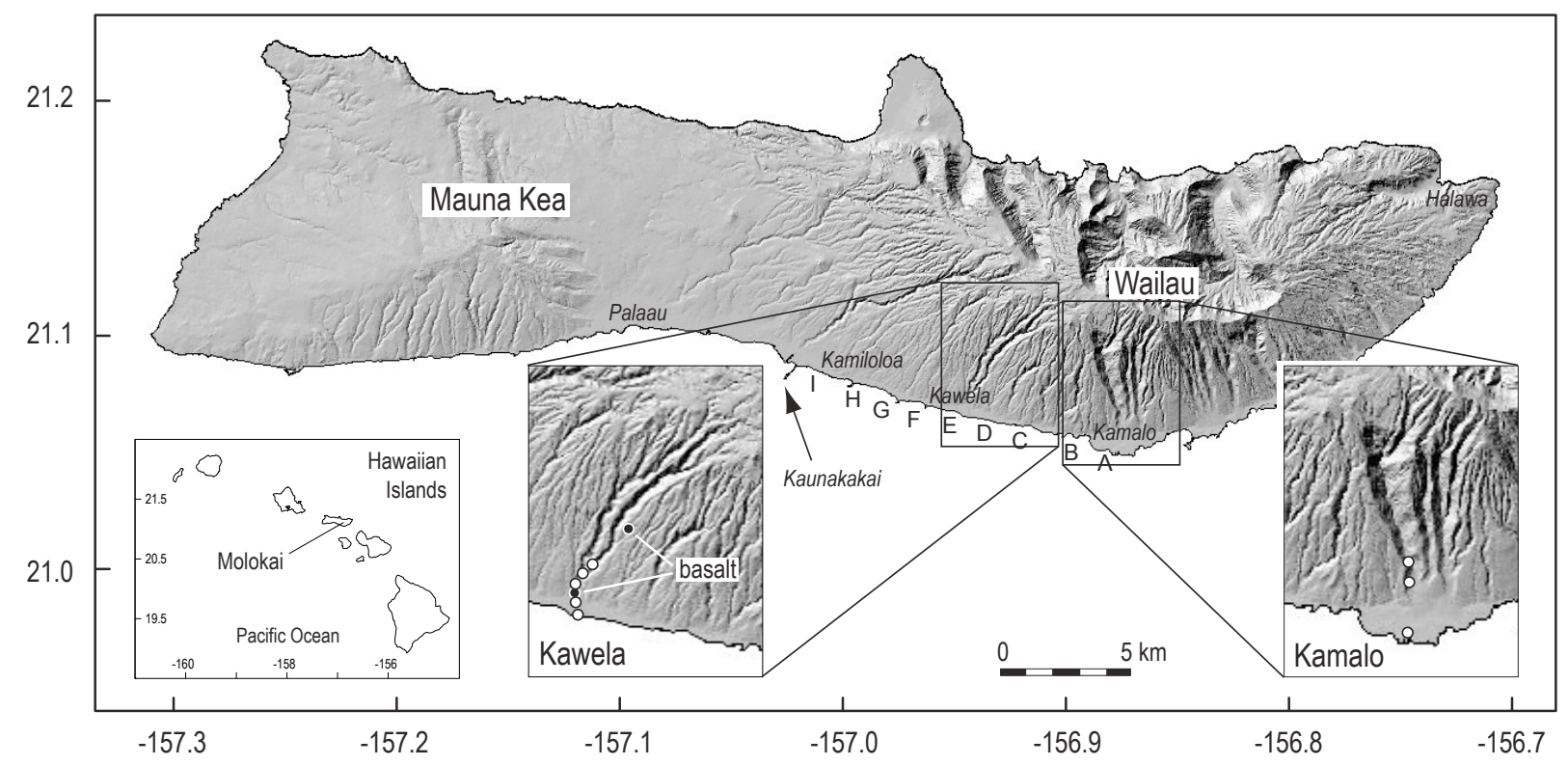

Figure 1. Map of Molokai and reef-flat transects designated by letters. Letter size shows transect length. Insets show the location of Molokai in the Hawaiian island chain, and upland sampling locations in Kawela and Kamalo watersheds. Filled circles are basalt; open circles are stream sediment. 
Molokai's south shore is protected from energetic winter waves (the North Pacific Swell) propagating from the north, and from southern swells and Kona-storm waves by the three islands to the south of Molokai (Field and others, 2008b; Storlazzi and others, 2008). The combination of an elongate coastline and wave-sheltered environment contribute to the establishment of an extensive fringing coral reef on the south shore of Molokai (Storlazzi and others, 2008). The south Molokai reef is the longest fringing reef in the main Hawaiian Islands.

Wailau (1,515 m elevation) is more than 3 times higher than Mauna Kea (434 m elevation). Because of its high elevation, Wailau receives orographic precipitation when warm, humid air masses of the trade winds ascend its slopes and condensation occurs (Stearns and MacDonald, 1947). Mean annual precipitation at the summit of Wailau is $400 \mathrm{~cm} / \mathrm{yr}$, but much of the rainfall infiltrates porous basalt aquifers and does not constitute surface runoff. Ephemeral streams in Kawela and Kamalo Gulches provide the only inputs of land-derived runoff to the reef flat between Kamalo and Kaunakakai (Stearns and MacDonald, 1947; Oki, 1997).

\section{Methods}

The south-southeast shore of Molokai and its watersheds were chosen as the study area due to the presence of an extensive fringing reef and high turbidity from terrigenous sediment associated with Kawela Stream.

\section{Sediment and Rock Collection}

\section{Upland Sediment and Basalt}

In the Kawela watershed, streambed sediment was collected from Kawela Stream mouth to about $2 \mathrm{~km}$ upstream (fig. 1). In addition, two types of basalt were collected to determine whether gulch and hillside basalt were geochemically distinct. One specimen of fresh, unweathered rock was chipped from a basalt column near the base of the canyon wall in Kawela Gulch. The second specimen was chipped from hillside bedrock exposed by a road grader above the east fork of Kawela Stream. In the Kamalo watershed, streambed sediment was collected from just below the highway bridge to about $2 \mathrm{~km}$ upstream (fig. 1).

\section{Nearshore Sediment}

Nearshore sediment was collected from the reef flat along nine cross-shore transects between the town of Kaunakakai and Kamalo Gulch (fig. 1). Bottom sediment was scooped from the seabed in plastic jars at distances 50,100, 250, 400, 550 and $700 \mathrm{~m}$ from the shore.

\section{Sediment Processing}

\section{Upland and Nearshore Sediment}

Sediment from eight reef-flat transects (thirty five sites; table 1) and nine upland sites was processed for elemental analyses at the U.S. Geological Survey (USGS) Geochemistry Lab in Menlo Park, California. Sediment from Transect F was not analyzed due to time constraints. Sediment was dried overnight at 60 degrees celsius, homogenized in an agate mortar and pestle, split into $\sim 2 \mathrm{~g}$ aliquots, and dry-sieved to separate the fine fraction (silt and clay, $<63 \mu \mathrm{m}$ diameter). The fine fraction was used for geochemical analyses to preclude artifacts due to differences in sediment grain-size distributions among samples. Carbonate was not removed 
from the fine fraction prior to acid digestion. About $14 \mathrm{mg}$ of fine sediment was digested in a 10 $\mathrm{ml}$ mixture of concentrated hydrofluoric and nitric acids in a microwave-assisted digestion system (MARS X, CEM Corp.) according to U.S. Environmental Protection Agency Method 3052. Digested solutions were evaporated to dryness on a hotplate at 180 degrees celsius, then reconstituted in 2 percent nitric acid containing a 100 parts per billion germanium $(\mathrm{Ge})$ internal standard.

Table 1. Locations of nearshore sediment used for geochemical analyses, Molokai reef-flat, Hawaii. [Numbers show the distance of each station from the shoreline.]

\begin{tabular}{|c|c|c|c|c|c|c|c|}
\hline \multirow[b]{2}{*}{ Line } & \multirow[b]{2}{*}{ Site name and features } & \multicolumn{6}{|c|}{ Distance from shore in meters } \\
\hline & & 50 & 100 & 250 & 400 & 550 & 700 \\
\hline A & Kamahuehue fish pond & $\mathrm{X}$ & $\mathrm{X}$ & $\mathrm{X}$ & & $\mathrm{X}$ & $\mathrm{X}$ \\
\hline B & Pahoa & $\mathrm{X}$ & & & $\mathrm{X}$ & & \\
\hline $\mathrm{C}$ & Panahaha & $x$ & $x$ & $x$ & & $x$ & $x$ \\
\hline $\mathrm{D}$ & Kakahaia & $x$ & & & $x$ & & \\
\hline E & Kawela Stream mouth & $\mathrm{X}$ & $\mathrm{X}$ & $\mathrm{X}$ & $\mathrm{X}$ & $\mathrm{X}$ & $\mathrm{X}$ \\
\hline $\mathrm{F}$ & One Alii park & & & & & & \\
\hline G & West of Alii fish pond & $\mathrm{X}$ & $x$ & $x$ & $x$ & $x$ & \\
\hline $\mathrm{H}$ & Kamiloloa & $x$ & $X$ & $\mathrm{x}$ & & $x$ & $\mathrm{X}$ \\
\hline I & Kapaakea (<1.5 km west of Kaunakakai wharf) & $\mathrm{X}$ & $\mathrm{X}$ & $\mathrm{X}$ & & $\mathrm{X}$ & $\mathrm{X}$ \\
\hline
\end{tabular}

\section{Basalt}

Basalt rocks were sent to the USGS Analytical Chemistry Lab in Denver, Colorado, to be crushed, sieved, and analyzed. Basalt aliquots used for trace-element determinations were digested with a four-acid mixture (Briggs and Meier, 2002). Basalt aliquots used for rare-earth and volatile-element determinations were soluablized by sintering with sodium peroxide (Meier and Slowik, 2002).

\section{Total-Element Analyses}

Major- and trace-element contents (appendices 1 and 2) for aluminum (Al), arsenic (As), barium $(\mathrm{Ba})$, calcium $(\mathrm{Ca})$, cadmium $(\mathrm{Cd})$, cobalt $(\mathrm{Co})$, chromium $(\mathrm{Cr})$, copper $(\mathrm{Cu})$, iron $(\mathrm{Fe})$, magnesium $(\mathrm{Mg})$, manganese $(\mathrm{Mn})$, molybdenum $(\mathrm{Mo})$, sodium $(\mathrm{Na})$, nickel $(\mathrm{Ni})$, lead $(\mathrm{Pb})$, strontium $(\mathrm{Sr})$, thorium $(\mathrm{Th})$, titanium $(\mathrm{Ti})$, uranium $(\mathrm{U})$, vanadium $(\mathrm{V})$, and zinc $(\mathrm{Zn})$ of upland and nearshore sediment, were determined by magnetic sector inductively-coupled plasma mass spectrometry (ICP-MS; Thermo Finnigan Element) at the University of California at Santa Cruz Marine Analytical Laboratory. The Ge internal standard was used to correct for instrumentsensitivity drift. Marine (NIST 2702), estuarine (NIST 1646a), and stream (STSD2, STSD3) sediment reference materials and procedural blanks were processed in parallel with Molokai sediment. Linear relationships between count intensities and certified element contents were used to calculate element contents of unknown samples. Reference material STSD2 was analyzed at regular intervals to determine accuracy and precision of measurements. The accuracy of element determinations averaged 2.3 percent of certified values. Precision of measurements averaged 1.2 percent. Detection limits, calculated as three times the standard deviation of the blank, were at least three times lower than the lowest sample concentration. Sediment from 'Kawela val' had extremely high $\mathrm{Cr}, \mathrm{Cu}, \mathrm{Ni}$, and $\mathrm{Pb}$ contents compared to all other upland samples (appendix 2) and was omitted from calculations and interpretations. 
Trace- and rare-earth element contents of basalt were determined by ICP-MS at the USGS Analytical Chemistry Lab in Denver, Colorado, and analytical performance of these methods are described in Briggs and Meier (2002) and Meier and Slowik (2002). Major-element contents of sediment are reported as weight percent; trace- and rare-earth element contents are reported as parts per million (ppm).

\section{Results and Discussion}

There are two types of sediment on the Molokai reef flat, carbonate sediment derived from calcareous skeletons of marine organisms and land-derived terrigenous sediment weathered from basalt lava flows (Field and others, 2008a). Bothner and others (2006) found that terrigenous sediment collected in nearshore sediment traps offshore of separate watersheds (Palaau, Kamiloloa) had distinct geochemical signatures, or fingerprints, based on $\mathrm{Cu} / \mathrm{Fe}$ ratios and magnetite contents. This suggests that if geochemical fingerprints of individual watersheds or of regions of watersheds (that is, gulches versus hillsides) can be identified, it may be possible to distinguish sources of terrigenous runoff to the fringing reef.

\section{Gulch and Hillside Basalt Compositions}

The two types of basalt from Kawela Gulch and the hillside above east Kawela were expected to have the greatest geochemical difference among the upland samples. Unlike streambed sediment they were unweathered and were collected in place, so had not undergone alteration during weathering and transport. Basalt in Kawela Gulch had higher contents of major $(\mathrm{Fe}, \mathrm{Mg})$ and trace elements associated with olivine $(\mathrm{Co}, \mathrm{Ni})$, clinopyroxene $(\mathrm{Cr}, \mathrm{Ti})$, and calcic plagioclase (Ca) compared to hillside basalt above the east fork of Kawela Stream (table 2). Copper and $\mathrm{V}$ were also enriched in gulch basalt. Hillside basalt, deposited during a later eruptive stage than basalt in Kawela Gulch, had higher contents of elements associated with alkali feldspar (K, Na), rare-earth elements, and Ba (table 2). Barium, K, and U contents were more than 10 times higher in hillside basalt compared to basalt in Kawela Gulch. These geochemical differences are consistent with the occurrence of alkali basalt on the hillside above east Kawela and tholeiitic basalt in Kawela Gulch (Clague and Beeson, 1980).

Table 2. Major-, trace-, and rare-earth element contents of Kawela basalt, Molokai reef-flat, Hawaii. [wt \%, weight percent; ppm, parts per million. 1 wt \% = 1 x 104 ppm.]

\begin{tabular}{|c|c|c|c|c|c|c|c|c|c|c|c|}
\hline & \multicolumn{11}{|c|}{ Elements associated with tholeiitic basalt } \\
\hline & \multicolumn{3}{|c|}{ Major-elements, in wt \% } & & \multicolumn{7}{|c|}{ Trace-elements, in ppm } \\
\hline & $\mathrm{Ca}$ & $\mathrm{Mg}$ & $\mathrm{Fe}$ & & $\mathrm{Ti}$ & Co & $\mathrm{Cr}$ & $\mathrm{Cu}$ & $\mathrm{Ni}$ & Sc & $\mathrm{V}$ \\
\hline Gulch basalt & 8.2 & 4.3 & 8.8 & & 1.6 & 46.0 & 310.0 & 118.0 & 86.0 & 35.0 & 345 \\
\hline \multirow[t]{4}{*}{ Hillside basalt } & 3.5 & 1.2 & 6.5 & & 0.9 & 7.0 & 3.5 & 7.7 & 5.3 & 5.8 & 23 \\
\hline & \multicolumn{11}{|c|}{ Elements associated with alkalic basalt } \\
\hline & \multirow{2}{*}{\multicolumn{3}{|c|}{\begin{tabular}{c}
\multicolumn{3}{l}{ Major-elements, in wt \% } \\
$\mathrm{K}$
\end{tabular}}} & \multicolumn{8}{|c|}{ Trace- and rare-earth elements, in ppm } \\
\hline & & & & $\mathrm{Ba}$ & La & $\mathrm{Nb}$ & $\mathrm{Rb}$ & Th & $\mathrm{U}$ & $\bar{Y}$ & $\mathrm{Zr}$ \\
\hline Gulch basalt & 0.2 & 1.7 & & 70.0 & 11 & 6.8 & 2.4 & 0.6 & 0.2 & 23 & 101 \\
\hline Hillside basalt & 1.9 & 4.1 & & 1280 & 158 & 75.0 & 36.0 & 5.8 & 1.9 & 78 & 444 \\
\hline
\end{tabular}

\section{Elements Associated with Marine Sources}

Upland soil and sediment had an average Ca content of $2 \pm 1$ weight percent $(1 \sigma)$ and ranged from 1 to 4 weight percent. The median $\mathrm{Ca}$ content of terrigenous material was 1 weight 
percent. In comparison, the Ca content of the fine fraction of nearshore sediment averaged $14 \pm 8$ weight percent $(1 \sigma)$ and ranged from 3 to 33 weight percent. The median Ca content of bottom sediment was 12 percent. The order of magnitude higher Ca content of nearshore sediment reflects the contribution of marine carbonates to the chemical composition of nearshore sediment. Ca contents of nearshore sediment generally increased with distance offshore (fig. 2A), consistent with the increase in the calcium-carbonate fraction of bottom sediment (Presto and others, 2006; Field and others, 2008a). Sr and U were strongly correlated with $\mathrm{Ca}$ in nearshore sediment, $r=0.99$ and $r=0.71$, respectively (for example, fig. $3 A$ ). $\mathrm{Sr}$ and $\mathrm{U}$ are readily incorporated into coral aragonite (Dodd, 1967; Milliman, 1974), and as a result, their nearshore distributions co-vary with that of carbonate sediment. Nearshore sediment contained small amounts of sea salt that could have influenced $\mathrm{Na}$ and $\mathrm{Mg}$ contents of nearshore sediment. The lack of strong correlations between $\mathrm{Na}$ or $\mathrm{Mg}$ and any other element suggests this was indeed the case. $\mathrm{Ca}, \mathrm{Mg}, \mathrm{Na}, \mathrm{Sr}$, and $\mathrm{U}$ contents of nearshore sediment were not indicative of terrigenous inputs and will not be discussed further.

\section{Terrigenous-Sediment Tracers}

Aluminum and Fe are major components of basalt and red basaltic soil of Molokai (Beeson, 1976; Xu and others, 2005) and are therefore good tracers of terrigenous sediment in coral reef environments. The $\mathrm{Al}$ and $\mathrm{Fe}$ contents of nearshore sediment generally decreased with distance from the coast, consistent with their terrigenous origin (fig. $2 B, C$ ). Iron contents of sediment collected east of Kawela Stream were lower than those collected to the west and directly offshore of Kawela. Sediment offshore of Kamalo Stream (Line A) had the lowest average Fe content, while that offshore of the town of Kaunakakai (Line I) had the highest. Many trace metals in nearshore sediment were strongly correlated with $\mathrm{Fe}(r>0.7)-\mathrm{Cd}, \mathrm{Cr}, \mathrm{Mo}, \mathrm{Ni}$, and $\mathrm{Zn}$ (for example, fig. $3 B$ ), as were major elements $\mathrm{Mn}$ and $\mathrm{Ti}$ ( $r>0.9$; for example, fig. $3 C$ ), suggesting their association with ferromagnesian minerals. Al is indicative of aluminosilicate and clay minerals (Windom and others, 1989). Unlike Fe, sedimentary Al contents showed no clear eastto-west pattern. Elements strongly correlated with $\mathrm{Al}(r>0.7)$ included $\mathrm{Ba}, \mathrm{Cd}$, and $\mathrm{Th}$ (for example, fig. $3 D$ ). Since Al contents of basalt were not quantified by the Denver Analytical Chemistry Lab, Th is used as the basis for comparison among upland and nearshore material. Th was chosen as a proxy for Al because the correlation coefficient between Al and Th in nearshore sediment was $r=0.92$, and $\mathrm{Th}$ is relatively immobile in sediment during weathering and transport (McLennan and others, 1990; Condie, 1993; Fralick and Kronberg, 1997). Ba $(r=0.96)$ and Cd $(r=0.85)$ were strongly correlated with Th in nearshore sediment.

\section{Sediment Provenance and Alongshore Mixing}

Previous studies of Molokai basalt geochemistry found that $\mathrm{Cu}$ contents varied erratically with stratigraphic position, that is, across eruptive sequences (Clague and Beeson, 1980). It is perhaps this characteristic that gives separate watersheds distinct $\mathrm{Cu} / \mathrm{Fe}$ signatures. Distinct $\mathrm{Cu} / \mathrm{Fe}$ ratios offshore of geographically separate regions of the south Molokai shore (Bothner and others, 2006) support this notion. Copper is mobilized from parent rocks during weathering and becomes strongly bound to organic matter in soil (Teutsch and others, 1999). Our analytical procedure does not allow us to distinguish between $\mathrm{Cu}$ bound to organic matter and $\mathrm{Cu}$ in crystalline phases (minerals); however, $\mathrm{Cu}$ was strongly correlated $(r>0.7)$ with relatively immobile ferromagnesian trace elements $(\mathrm{Co}, \mathrm{Cr}$, and $\mathrm{Ni})$ in nearshore sediment, suggesting that a large fraction of $\mathrm{Cu}$ was incorporated in mineral grains. 

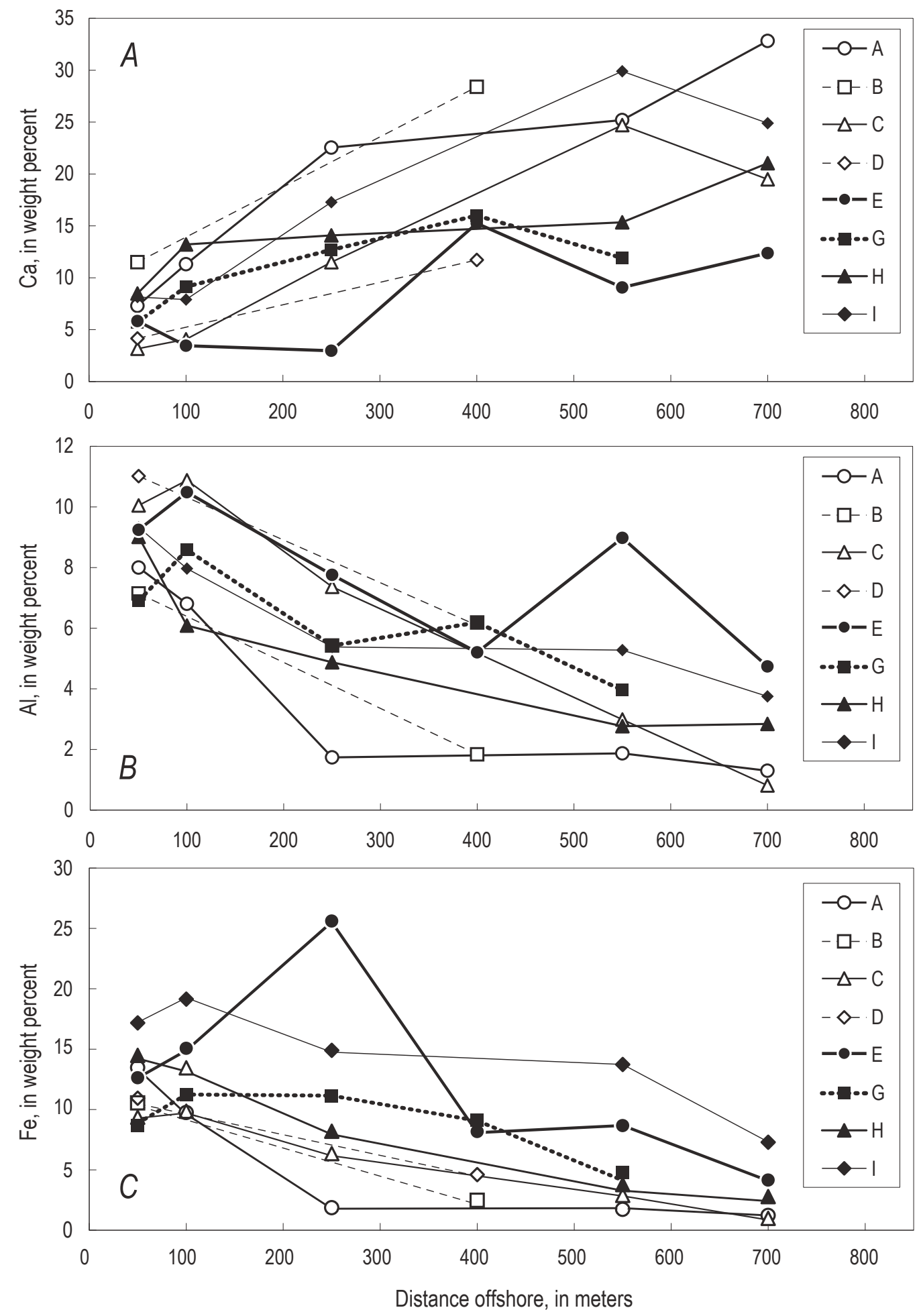

Figure 2. Variations of sediment composition along cross-shore transects as a function of distance from shore, Molokai reef-flat, Hawaii. $A, \mathrm{Ca} ; B, \mathrm{Al}$; and $C$, Fe. 

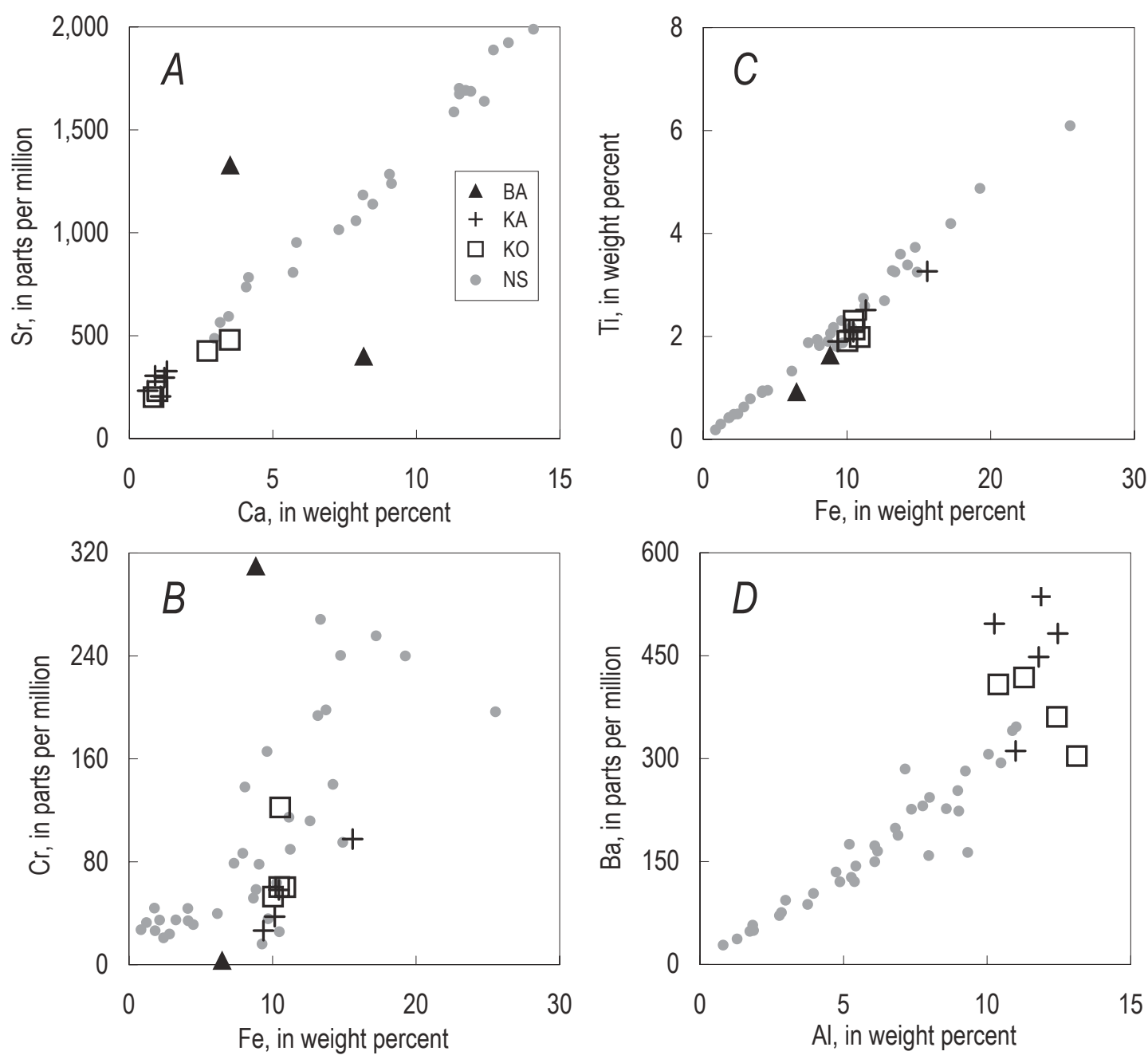

Figure 3. Comparisons of elemental compositions of basalt, upland sediment, and nearshore sediment, Molokai, Hawaii. $A, \mathrm{Sr}$ versus $\mathrm{Ca}, B, \mathrm{Cr}$ versus $\mathrm{Fe}, \mathrm{C}$, Ti versus $\mathrm{Fe}$, and $D$, Ba versus $\mathrm{Al}$. $\mathrm{BA}$ is basalt; $\mathrm{KA}$ is Kawela; KO is Kamalo; NS is nearshore.

\section{Kawela and Western Transects (Lines G-I)}

There was more than an order of magnitude difference in $\mathrm{Cu}$ contents of gulch (tholeiitic) and hillside (alkalic) basalt (fig. 4). Kawela streambed sediment, with an average $\mathrm{Cu}$ content of $22 \mathrm{ppm}$, was more similar to hillside basalt (8 ppm) than to tholeiitic basalt in canyon walls (118 $\mathrm{ppm}$ ), suggesting that Kawela Stream sediment may have originated on hillsides above the gulch. The average $\mathrm{Cu} / \mathrm{Fe}$ ratio in the western-most part of the study area (Lines G-I), $1.5-1.8 \pm 0.4 \times 10^{-}$ ${ }^{4}(1 \sigma)$, was not significantly different from the average ratio of hillside basalt and Kawela streambed sediment, $1.7 \pm 0.4 \times 10^{-4}(1 \sigma)$, suggesting that terrigenous sediment in the western part of the study area originated on hillsides in the Kawela watershed, was transported to the nearshore in Kawela Stream, and across the reef flat by westward alongshore flow (Ogston and others, 2004; Presto and others, 2006). It is less likely that terrigenous sediment in the western part of the study area originated from a local upland source because modern downslope sediment transport into the nearshore is not straightforward. King Kamehameha highway and beach-front 
residences have all but eliminated connectivity between uplands and the nearshore between Kaunakakai and Kawela.

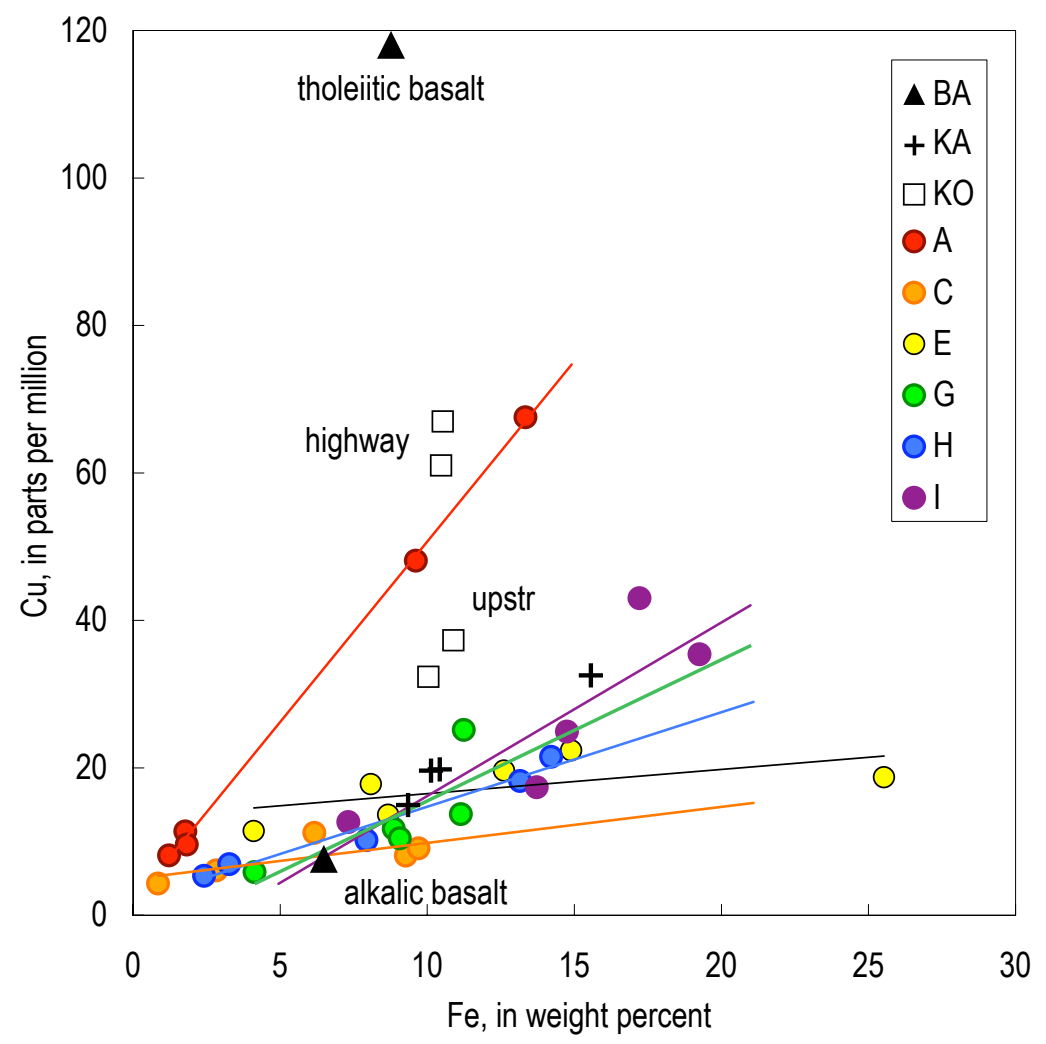

Figure 4. Comparison of Cu to Fe contents of basalt, upland sediment, and nearshore sediment, Molokai, Hawaii. Lines are least-squares regression lines. highway is sediment sampled just below the highway bridge over Kamalo Stream, upstr is sediment sampled $2 \mathrm{~km}$ upstream of Kamalo mouth. BA is basalt; $\mathrm{KA}$ is Kawela; KO is Kamalo; NS is nearshore.

\section{Kamalo and the Eastern Transect (Line A)}

The average $\mathrm{Cu} / \mathrm{Fe}$ ratio of sediment near the highway bridge over Kamalo Stream, $6.1 \pm 0.4 \times 10^{-}$ ${ }^{4}(1 \sigma, \mathrm{n}=2)$, was distinct from that of sediment $2 \mathrm{~km}$ upstream, $3.3 \pm 0.1 \times 10^{-4}(1 \sigma, \mathrm{n}=2)$. The average $\mathrm{Cu} / \mathrm{Fe}$ ratio along Line A, $5.7 \pm 0.8 \times 10^{-4}$, was similar to that near the highway bridge and about three times higher than that in nearshore sediment west of Kamalo (fig. 4). The similarity of $\mathrm{Cu} / \mathrm{Fe}$ ratios in Line A and Kamalo sediment suggests that Kamalo watershed was the source of sediment to the reef flat near Kamahuehue (Line A). Average $\mathrm{Cu} / \mathrm{Fe}$ ratios were significantly different along Lines B-C compared to Line A, however, suggesting weak mixing just a few kilometers to the west. This is surprising given the prevalence of northeast trade winds and westward alongshore flow over the reef flat (Ogston and others, 2004; Presto and others, 2006; Ogston and others, 2008). If there is indeed a discontinuity in alongshore flow downstream of Kamahuehue, it could be related to the change in coastline orientation at Kamalo. Kamalo is the southern-most point of Molokai and the coastline trends about 70 degrees from true north on the east and about 110 from true north on the west. As a result, the reef flat directly west of Kamalo (in the vicinity of Lines B and C) is protected from the trade winds (Storlazzi and others, 
2008) and could experience less vigorous wind-driven alongshore transport than in the region beyond the wind shadow. Furthermore, if trade wind-driven transport is directed to the west or southwest, as predicted by Ogston and others (2008), suspended sediment from Kamalo Stream would be advected toward the outer portion of the reef flat at Lines B and C.

\section{Sediment Transport to the Outer Reef-Flat}

Evidence from another suite of geochemical tracers $(\mathrm{Cd}, \mathrm{Co}, \mathrm{Th})$ lends support to the notion that suspended sediment transported west from Kamalo could be deposited on the adjacent outer reef flat. Th and Co are relatively resistant to weathering and should reflect parent rock compositions (McLennan and Taylor, 1980; Vital, Stattegger, and Garbe-Schonberg, 1999). $\mathrm{Cd}$ was likely associated with aluminosilicate minerals since it was strongly correlated with $\mathrm{Th}$. Most nearshore sediment had Th-normalized $\mathrm{Cd}$ and Co contents that fell along a mixing line between alkalic and tholeiitic basalt (fig. 5). However, sediment on the mid- to outer-reef flat (400-700 $\mathrm{m}$ from shore) along Lines A-C had high $\mathrm{Cd} / \mathrm{Th}$ ratios relative to the mixing line. Sediment at A050 was an exception to this pattern, and it has a composition similar to sediment at the mouth of Kamalo Stream. The surficial geology from Kamalo to Halawa (the easternmost point of Molokai) consists of relatively little alkalic basalt (Oki, 1997), which could explain why sediment originating in or east of Kamalo might have higher $\mathrm{Cd}$ and Co contents. Elevated $\mathrm{Cd} / \mathrm{Th}$ ratios in Kamalo Stream sediment are consistent with a more tholeiitic composition than Kawela sediment (fig. 5). We did not evaluate whether the Th-scavenging efficiencies differed along Lines A-C compared to the rest of the study area because such determinations were beyond the scope of this study.

\section{Summary}

Chemical compositions of basalt, upland soil, and nearshore sediment were measured along the south-southeast shore of Molokai, Hawaii, to determine whether geochemical tracers of terrigenous runoff could be identified in nearshore sediment and to explore whether separate watersheds or regions of watersheds had distinct geochemical signatures, or fingerprints, that would allow determination of runoff provenance. The elements $\mathrm{Mg}, \mathrm{Na}, \mathrm{Sr}$, and $\mathrm{U}$ were strongly influenced by a large marine source (in the form of biogenic calcium carbonate or sea salt), and were not useful geochemical tracers of terrigenous inputs to the south Molokai reef flat. Fe and elements associated with ferromagnesian minerals ( $\mathrm{Mn}, \mathrm{Ti}, \mathrm{Cr}, \mathrm{Mo}, \mathrm{Ni}$, and $\mathrm{Zn}$ ), and $\mathrm{Al}$ and elements associated with aluminosilicate minerals $(\mathrm{Ba}, \mathrm{Cd}, \mathrm{Th})$ were robust tracers of terrigenous inputs to the nearshore. Sedimentary $\mathrm{Cu} / \mathrm{Fe}$ ratios showed that the hillsides over Kawela Gulch were the main source of sediment runoff to the reef flat. Identification of runoff sources can help erosion-mitigation projects target problematic areas of watersheds. Sedimentary $\mathrm{Cd} / \mathrm{Th}$ ratios suggest terrigenous sediment on the outer reef flat in the eastern part of the study area originated to the east of Kamalo Gulch. This sediment could have been transported into the study area by westward alongshore currents (Ogston and others, 2004; Presto others, 2006; Ogston and others, 2008). 

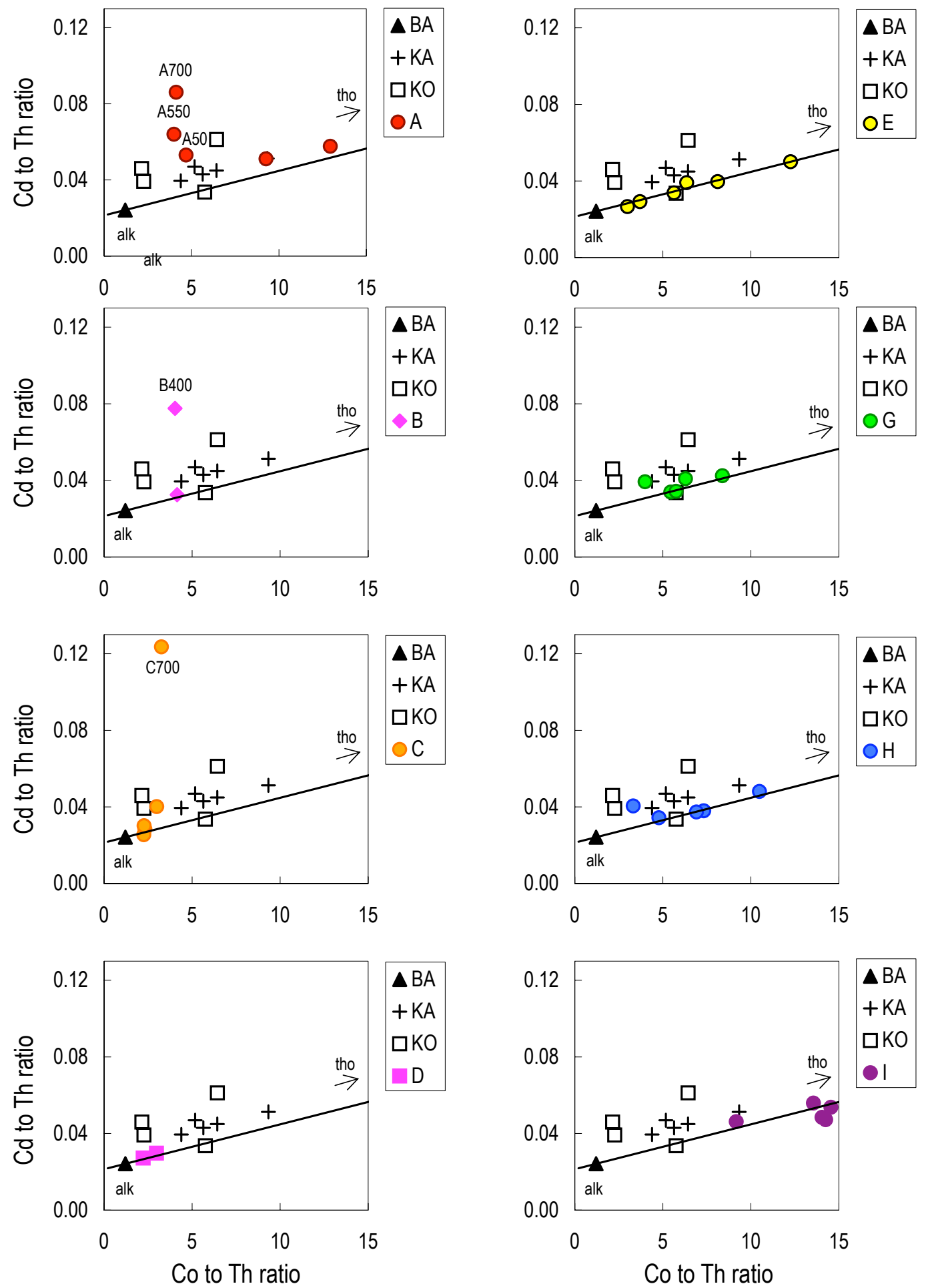

Figure 5. Comparisons of $\mathrm{Cd} / \mathrm{Th}$ and $\mathrm{Co} / \mathrm{Th}$ ratios in basalt, upland sediment, and nearshore sediment, Molokai, Hawaii. The line in each plot is a compositional mixing line between alkalic (alk) and tholeitic (tho) basalt. Labels show transect (letter) and distance from shore (number) of nearshore sites with elevated $\mathrm{Cd} / \mathrm{Th}$ ratios. BA is basalt; KA is Kawela; KO is Kamalo; NS is nearshore. 


\section{Acknowledgments}

The authors thank Barry Hill and Jon Stock for assistance collecting upland sediment; Rob Franks at the University of California at Santa Cruz Marine Analytical Laboratory for help with ICP-MS analyses; and Nancy Grumet-Prouty, Christopher Conaway, and Curt Storlazzi for suggestions that improved the manuscript.

\section{References}

Beeson, M.H., 1976, Petrology, mineralogy, and geochemistry of the East Molokai volcanic series: U.S. Geological Survey Professional Paper 961.

Bothner, M.H., Reynolds, R.L., Casso, M.A., Storlazzi, C.D., and Field, M.E., 2006, Quantity, composition and source of sediment collected in sediment traps along the fringing coral reef off Molokai, Hawaii: Marine Pollution Bulletin, v. 52, p. 1034-1047.

Briggs, P.H., and Meier, A.L., 2002, The determination of forty-two elements in geological materials by inductively coupled-plasma mass spectrometry, U.S. Geological Survey Open-File Report 02-223-I.

Carr, R.S., and Nipper, M., 2008, Measurements of toxicity in reef sediments, in Field, M.E., Cochran, S.A., Logan, J.B., and Storlazzi, C.D., eds., The coral reefs of south Moloka'i, Hawai 1 - Portrait of a sediment-threatened fringing reef: U.S. Geological Survey Scientific Investigation Report 2007-5101, p. 145-146.

Clague, D.A., and Beeson, M.H., 1980, Trace element geochemistry of the East Molokai volcanic series, Hawaii: American Journal of Science, v. 280A, p. 820-844.

Condie, K.C., 1993, Chemical composition and evolution of the upper continental crustContrasting results from surface samples and shales: Chemical Geology, v. 104, p. 1-37.

Dodd, R.J., 1967, Magnesium and strontium in calcareous skeletons- A review: Journal of Paleontology, v. 41, no. 6, p. 1313-1329.

Field, M.E., Calhoun, R.S., Storlazzi, C.D., Logan, J.B., and Cochran, S.A., 2008a, Sediment on the Moloka i reef, in Field, M.E., Cochran, S.A., Logan, J.B., and Storlazzi, C.D., eds., The coral reefs of south Moloka 'i, Hawai $i$ - Portrait of a sediment-threatened fringing reef: U.S. Geological Survey Scientific Investigation Report 2007-5101, p. 137-144.

Field, M.E., Cochran, S.A., Logan, J.B., and Storlazzi, C.D., 2008b, The Moloka'i coral reef today, and alternatives for the future, in Field, M.E., Cochran, S.A., Logan, J.B., and Storlazzi, C.D., eds., The coral reefs of south Moloka i, Hawai i- Portrait of a sedimentthreatened fringing reef: U.S. Geological Survey Scientific Investigation Report 20075101, p. 167-170.

Fralick, P.W., and Kronberg, B.I., 1997, Geochemical discrimination of clastic sedimentary rock sources: Sedimentary Geology, v. 113, p. 111-124.

Jokiel, P.L., Brown, E.K., Rodgers, K.S., and Smith, W.R., 2008, Reef corals and coral reefs of south Moloka 'i, in Field, M.E., Cochran, S.A., Logan, J.B., and Storlazzi, C.D., eds., The coral reefs of south Moloka i, Hawai $i-$ Portrait of a sediment-threatened fringing reef:

U.S. Geological Survey Scientific Investigation Report 2007-5101, p. 43-50.

McLennan, S.M., and Taylor, S.R., 1980, Th and U in sedimentary rocks- Crustal evolution and sedimentary recycling: Nature, v. 285, p. 621-624.

McLennan, S.M., Taylor, S.R., McCulloch, M.T., and Maynard, J.B., 1990, Geochemical and $\mathrm{Nd}-\mathrm{Sr}$ isotopic compositions of deep-sea turbidites-Crustal evolution and plate tectonic associations: Geochimica et Cosmochimica Acta, v. 54, p. 2015-2050. 
Meier, A.L., and Slowik, T., 2002, Rare earth elements by inductively coupled plasma-mass spectrometry, U.S. Geological Survey Open File Report 02-223-K.

Milliman, J.D., 1974, Marine carbonates: New York, Springer-Verlag, 375 p.

Ogston, A.S., Presto, M.K., Storlazzi, C.D., and Field, M.E., 2008, Causes of turbidity on the Moloka i reef flat and resulting sediment-transport patterns, in Field, M.E., Cochran, S.A., Logan, J.B., and Storlazzi, C.D., eds., The coral reefs of south Moloka 'i, Hawai' iPortrait of a sediment-threatened fringing reef: U.S. Geological Survey Scientific Investigation Report 2007-5101, p. 153-158.

Ogston, A.S., Storlazzi, C.D., Field, M.E., and Presto, M.K., 2004, Sediment resuspension and transport patterns on a fringing reef flat, Molokai, Hawaii: Coral Reefs, v. 23, p. 559-569.

Oki, D.S., 1997, Geohydrology and numerical simulation of the ground-water flow system of Molokai, Hawaii: U.S. Geological Survey Water-Resources Investigations Report 974176.

Presto, M.K., Ogston, A.S., Storlazzi, C.D., and Field, M.E., 2006, Temporal and spatial variability in the flow and dispersal of suspended-sediment on a fringing reef flat, Molokai, Hawaii: Estuarine, Coastal and Shelf Science, v. 67, p. 67-81.

Roberts, L.M., and Field, M.E., 2008, People, land and the reefs of South Moloka i, in Field, M.E., Cochran, S.A., Logan, J.B., and Storlazzi, C.D., eds., The coral reefs of south Moloka 'i, Hawai ' 1 - Portrait of a sediment-threatened fringing reef: U.S. Geological Survey Scientific Investigation Report 2007-5101, p. 123-128.

Stearns, H.T., and MacDonald, G.A., 1947, Geology and ground-water resources of the island of Molokai, Hawaii: Hawaii Division of Hydrography, Bulletin 11.

Storlazzi, C.D., Brown, E.T., Field, M.E., and Jokiel, P.L., 2008, Waves and their impact on reef growth, in Field, M.E., Cochran, S.A., Logan, J.B., and Storlazzi, C.D., eds., The coral reefs of south Moloka $i$, Hawai $i$ - Portrait of a sediment-threatened fringing reef: U.S. Geological Survey Scientific Investigation Report 2007-5101, p. 105-110.

Taylor, S.R., and McLennan, S.M., 1985, The continental crust- Its composition and evolution: Oxford, England, Blackwell Scientific Publications, 312 p.

Teutsch, N., Erel, Y., Halicz, L., and Chadwick, O.A., 1999, The influence of rainfall on metal conentration and behavior in the soil: Geochimica et Cosmochimica Acta, v. 63, no. 21, p. 3499-3511.

Tribble, G., and Oki, D.S., 2008, The freshwater cycle on Moloka i, in Field, M.E., Cochran, J.K., Logan, J.B., and Storlazzi, C.D., eds., The coral reefs of south Moloka 'i, Hawai 'iPortrait of a sediment-threatened fringing reef: U.S. Geological Survey Scientific Investigation Report 2007-5101, p. 109-110.

Vital, H., Stattegger, K., and Garbe-Schonberg, C.-D., 1999, Composition and trace-element geochemistry of detrital clay and heavy-mineral suites of the lowermost Amazon RiverA provenance study: Journal of Sedimentary Research, v. 69, no. 3, p. 563-575.

Windom, H.L., Schropp, S.J., Calder, F.D., Ryan, J.D., Smith, R.G., Burnery, L.C., Lewis, F.G., and Rawlinson, C.H., 1989, Natural trace metal concentrations in estuarine and coastal marine sediments of the southeastern United States: Environmental Science and Technology, v. 23, p. 314-320.

Xu, G., Frey, F.A., Clague, D.A., Weis, D., and Beeson, M.H., 2005, East Molokai and other Kea-trend volcanoes: Magmatic processes and sources as they migrate away from the Hawaiian hot spot: Geochemistry Geophysics Geosystems, v. 6, no. 5, p. Q05008, doi $10.1029 / 2004 \mathrm{GC} 000830$. 
Appendix 1. Major-element compositions of basalt, upland sediment, and nearshore sediment, Molokai, Hawaii.

[n.d., not determined; br, highway bridge; confl, confluence of east and west forks; val, beginning of confined valley; $2 \mathrm{~km}, 2 \mathrm{~km}$ upstream. Site letters correspond to reef transects and numbers to distances from shore in meters. Units are wt \%. $1 \mathrm{wt} \%=1 \times 104 \mathrm{ppm}$.

\begin{tabular}{|c|c|c|c|c|c|c|c|c|}
\hline Site & $\mathrm{Al}$ & $\mathrm{Ca}$ & $\mathrm{Fe}$ & $\mathrm{K}$ & $\mathrm{Mg}$ & $\mathrm{Mn}$ & $\mathrm{Na}$ & $\mathrm{Ti}$ \\
\hline \multicolumn{9}{|c|}{ Basalt } \\
\hline Gulch basalt & n.d. & 8.2 & 8.8 & 0.2 & 4.3 & 0.1 & 1.7 & 1.6 \\
\hline Hillside basalt & n.d. & 3.5 & 6.5 & 1.9 & 1.2 & 0.2 & 4.1 & 0.9 \\
\hline \multicolumn{9}{|c|}{ Upland sediment } \\
\hline Kawela mouth & 11.9 & 0.6 & 9.4 & 0.4 & 0.5 & 0.2 & 0.8 & 1.9 \\
\hline Kawela br & 12.5 & 1.3 & 10.4 & 0.5 & 0.9 & 0.2 & 0.9 & 2.1 \\
\hline Kawela confl & 11.8 & 1.2 & 15.6 & 0.4 & 1.3 & 0.2 & 0.6 & 3.3 \\
\hline Kawela val & 11.0 & 1.1 & 11.3 & 0.5 & 0.7 & 0.1 & 0.3 & 2.5 \\
\hline Kawela $2 \mathrm{~km}$ & 10.3 & 0.9 & 10.1 & 0.5 & 0.6 & 0.2 & 1.0 & 2.1 \\
\hline Kamalo br1 & 11.3 & 2.7 & 10.5 & 0.7 & 1.2 & 0.2 & 1.5 & 2.3 \\
\hline Kamalo br2 & 13.1 & 0.8 & 10.9 & 0.4 & 0.6 & 0.2 & 0.5 & 2.0 \\
\hline Kamalo val & 12.4 & 1.0 & 10.0 & 0.4 & 0.7 & 0.2 & 0.6 & 1.9 \\
\hline Kamalo $2 \mathrm{~km}$ & 10.4 & 3.5 & 10.5 & 0.6 & 1.6 & 0.2 & 1.6 & 2.1 \\
\hline \multicolumn{9}{|c|}{ Nearshore sediment } \\
\hline A050 & 8.0 & 7.3 & 13.3 & 0.6 & 2.3 & 0.2 & 2.2 & 3.3 \\
\hline $\mathrm{A} 100$ & 6.8 & 11.3 & 9.6 & 0.4 & 1.8 & 0.1 & 2.2 & 2.3 \\
\hline $\mathrm{A} 250$ & 1.7 & 22.5 & 1.8 & 0.3 & 1.9 & 0.0 & 5.7 & 0.4 \\
\hline A550 & 1.9 & 25.2 & 1.8 & 0.3 & 2.1 & 0.0 & 3.4 & 0.4 \\
\hline A700 & 1.3 & 32.8 & 1.2 & 0.1 & 1.8 & 0.0 & 1.4 & 0.3 \\
\hline B050 & 7.1 & 11.5 & 10.3 & 0.5 & 1.4 & 0.2 & 2.1 & 2.2 \\
\hline B400 & 1.8 & 28.4 & 2.1 & 0.1 & 1.3 & 0.0 & 1.7 & 0.5 \\
\hline $\mathrm{C} 050$ & 10.1 & 3.2 & 9.3 & 0.5 & 0.7 & 0.2 & 1.6 & 1.8 \\
\hline $\mathrm{C} 100$ & 10.9 & 4.1 & 9.7 & 0.6 & 0.8 & 0.2 & 1.4 & 1.9 \\
\hline $\mathrm{C} 250$ & 7.4 & 11.5 & 6.2 & 0.5 & 1.4 & 0.1 & 2.9 & 1.3 \\
\hline C550 & 3.0 & 24.7 & 2.8 & 0.2 & 1.4 & 0.0 & 2.3 & 0.6 \\
\hline $\mathrm{C} 700$ & 0.8 & 19.5 & 0.8 & 0.1 & 0.8 & 0.0 & 0.8 & 0.2 \\
\hline D050 & 11.0 & 4.2 & 10.5 & 0.6 & 0.9 & 0.2 & 1.6 & 2.1 \\
\hline D400 & 6.1 & 11.7 & 4.5 & 0.5 & 1.5 & 0.1 & 6.6 & 1.0 \\
\hline E050 & 9.2 & 5.8 & 12.6 & 0.5 & 1.6 & 0.2 & 1.7 & 2.7 \\
\hline E100 & 10.5 & 3.5 & 14.9 & 0.5 & 1.4 & 0.2 & 1.4 & 3.2 \\
\hline E250 & 7.8 & 3.0 & 25.5 & 0.4 & 1.8 & 0.3 & 1.0 & 6.1 \\
\hline E400 & 5.2 & 15.2 & 8.1 & 0.5 & 1.7 & 0.1 & 6.3 & 1.8 \\
\hline E550 & 9.0 & 9.1 & 8.7 & 0.5 & 1.5 & 0.1 & 2.4 & 1.9 \\
\hline E700 & 4.7 & 12.4 & 4.1 & 0.6 & 2.0 & 0.1 & 8.4 & 0.9 \\
\hline G050 & 6.9 & 5.7 & 8.9 & 0.3 & 1.0 & 0.1 & 0.9 & 2.1 \\
\hline G100 & 8.6 & 9.1 & 11.2 & 0.5 & 1.5 & 0.2 & 1.9 & 2.6 \\
\hline G250 & 5.4 & 12.7 & 11.1 & 0.5 & 1.9 & 0.2 & 4.0 & 2.7 \\
\hline G400 & 6.2 & 16.0 & 9.1 & 0.4 & 1.5 & 0.1 & 2.0 & 2.2 \\
\hline G550 & 4.0 & 11.9 & 4.1 & 0.6 & 2.1 & 0.1 & 8.7 & 0.9 \\
\hline $\mathrm{H} 050$ & 9.0 & 8.5 & 14.2 & 0.4 & 1.4 & 0.2 & 0.9 & 3.4 \\
\hline H100 & 6.1 & 13.2 & 13.2 & 0.3 & 1.5 & 0.2 & 1.7 & 3.3 \\
\hline $\mathrm{H} 250$ & 4.9 & 14.1 & 7.9 & 0.5 & 2.0 & 0.1 & 5.5 & 1.9 \\
\hline
\end{tabular}


Appendix 1 (cont'd.)

\begin{tabular}{lrrrrrrrr}
\hline \multicolumn{1}{c}{ Site } & Al & \multicolumn{1}{c}{ Ca } & \multicolumn{1}{c}{ Fe } & K & Mg & Mn & Na & \multicolumn{1}{c}{ Ti } \\
\hline H550 & 2.8 & 15.3 & 3.3 & 0.6 & 2.1 & 0.1 & 10.9 & 0.8 \\
H700 & 2.8 & 21.0 & 2.4 & 0.4 & 2.2 & 0.0 & 6.3 & 0.5 \\
\hline I050 & 9.3 & 8.1 & 17.2 & 0.3 & 1.4 & 0.2 & 0.8 & 4.2 \\
I100 & 8.0 & 7.9 & 19.3 & 0.3 & 1.5 & 0.2 & 0.8 & 4.9 \\
I250 & 5.4 & 17.3 & 14.7 & 0.3 & 1.7 & 0.2 & 2.0 & 3.7 \\
I550 & 5.3 & 29.9 & 13.7 & 0.3 & 2.0 & 0.2 & 1.6 & 3.6 \\
I700 & 3.8 & 24.9 & 7.3 & 0.2 & 1.5 & 0.1 & 0.8 & 1.9 \\
\hline
\end{tabular}

Appendix 2. Trace-element compositions of basalt, upland sediment, and nearshore sediment, Molokai, Hawaii.

$[\mathrm{Cu} / \mathrm{Fe}$ ratios multiplied by $104, \mathrm{Cd} / \mathrm{Th}$ ratios multiplied by 102 . br, highway bridge; confl, confluence of east and west forks; val, beginning of confined valley; $2 \mathrm{~km}, 2 \mathrm{~km}$ upstream. Site letters correspond to reef transects and numbers to distances from shore in meters. Units are parts per million; <, below given value; *, data not used in calculations]

\begin{tabular}{|c|c|c|c|c|c|c|c|c|}
\hline Site & As & $\mathrm{Ba}$ & $\mathrm{Cd}$ & Co & $\mathrm{Cr}$ & $\mathrm{Cu}$ & Mo & $\mathrm{Ni}$ \\
\hline \multicolumn{9}{|c|}{ Basalt } \\
\hline Gulch basalt & $<1$ & 70 & 0.1 & 46 & 310 & 118 & 0.5 & 86 \\
\hline Hillside basalt & 1 & 1,280 & 0.1 & 7 & 4 & 8 & 1.8 & 5 \\
\hline \multicolumn{9}{|c|}{ Upland sediment } \\
\hline Kawela mouth & 1.8 & 536 & 0.2 & 32 & 26 & 15 & 1.3 & 23 \\
\hline Kawela br & 1.3 & 482 & 0.2 & 25 & 58 & 20 & 1.4 & 38 \\
\hline Kawela confl & 1.2 & 448 & 0.3 & 36 & 98 & 32 & 1.6 & 39 \\
\hline Kawela val & 1.4 & 311 & 0.2 & 41 & *304 & *144 & $* 2.9$ & $* 167$ \\
\hline Kawela $2 \mathrm{~km}$ & 1.0 & 497 & 0.2 & 25 & 37 & 20 & 1.1 & 30 \\
\hline Kamalo br1 & 2.0 & 418 & 0.2 & 34 & 60 & 61 & 1.6 & 45 \\
\hline Kamalo br2 & 4.3 & 304 & 0.4 & 21 & 60 & 37 & 2.2 & 35 \\
\hline Kamalo val & 3.1 & 361 & 0.4 & 21 & 53 & 32 & 1.8 & 37 \\
\hline Kamalo $2 \mathrm{~km}$ & 1.4 & 408 & 0.3 & 35 & 122 & 67 & 2.1 & 69 \\
\hline \multicolumn{9}{|c|}{ Nearshore sediment } \\
\hline $\mathrm{A} 050$ & 16.0 & 243 & 0.2 & 38 & 268 & 68 & 2.4 & 63 \\
\hline $\mathrm{A} 100$ & 18.5 & 199 & 0.1 & 25 & 166 & 48 & 1.7 & 41 \\
\hline A 250 & 11.2 & 48 & 0.1 & 5 & 44 & 11 & 0.9 & 18 \\
\hline A550 & 12.8 & 49 & 0.1 & 4 & 26 & 10 & 0.9 & 12 \\
\hline A700 & 8.7 & 37 & 0.1 & 3 & 33 & 8 & 1.2 & 12 \\
\hline B050 & 14.1 & 285 & 0.2 & 20 & 63 & 20 & 1.7 & 22 \\
\hline $\mathrm{B} 400$ & 10.4 & 57 & 0.1 & 4 & 35 & 7 & 0.8 & 12 \\
\hline $\mathrm{C} 050$ & 9.3 & 306 & 0.2 & 16 & 16 & 8 & 2.1 & 11 \\
\hline $\mathrm{C} 100$ & 11.3 & 341 & 0.2 & 16 & 36 & 9 & 1.6 & 21 \\
\hline $\mathrm{C} 250$ & 16.7 & 226 & 0.1 & 11 & 40 & 11 & 1.4 & 14 \\
\hline C550 & 13.7 & 93 & 0.1 & 6 & 24 & 6 & 0.8 & 10 \\
\hline $\mathrm{C} 700$ & 5.1 & 28 & 0.1 & 2 & 27 & 4 & 0.5 & 12 \\
\hline D050 & 10.2 & 346 & 0.2 & 19 & 26 & 10 & 1.7 & 15 \\
\hline D400 & 17.6 & 173 & 0.1 & 9 & 31 & 8 & 1.2 & 17 \\
\hline E050 & 12.2 & 282 & 0.2 & 29 & 112 & 20 & 2.4 & 37 \\
\hline E100 & 9.6 & 294 & 0.2 & 31 & 95 & 22 & 2.1 & 32 \\
\hline
\end{tabular}


Appendix 2 (cont'd).

\begin{tabular}{lrrrrrrrr}
\hline \multicolumn{1}{c}{ Site } & As & \multicolumn{1}{c}{ Ba } & \multicolumn{1}{c}{ Cd } & Co & Cr & Cu & Mo & Ni \\
\hline E250 & 10.9 & 231 & 0.2 & 53 & 197 & 19 & 3.0 & 34 \\
E400 & 25.6 & 175 & 0.1 & 20 & 138 & 18 & 1.7 & 46 \\
E550 & 21.0 & 253 & 0.1 & 18 & 52 & 14 & 1.5 & 21 \\
E700 & 16.2 & 135 & 0.1 & 8 & 44 & 11 & 1.5 & 15 \\
\hline G050 & 9.0 & 188 & 0.1 & 17 & 58 & 12 & 1.4 & 17 \\
G100 & 14.2 & 227 & 0.1 & 23 & 90 & 25 & 1.9 & 23 \\
G250 & 14.1 & 143 & 0.1 & 22 & 115 & 14 & 1.8 & 19 \\
G400 & 17.8 & 165 & 0.1 & 18 & 78 & 10 & 1.6 & 19 \\
G550 & 12.3 & 103 & 0.1 & 8 & 34 & 6 & 1.3 & 13 \\
\hline H050 & 13.5 & 223 & 0.2 & 30 & 140 & 21 & 2.6 & 33 \\
H100 & 13.4 & 150 & 0.1 & 28 & 194 & 18 & 2.7 & 41 \\
H250 & 13.8 & 120 & 0.1 & 16 & 87 & 10 & 1.5 & 18 \\
H550 & 9.1 & 71 & 0.0 & 7 & 35 & 7 & 0.9 & 11 \\
H700 & 17.8 & 76 & 0.1 & 5 & 21 & 5 & 1.1 & 9 \\
\hline I050 & 15.1 & 163 & 0.2 & 49 & 256 & 43 & 2.5 & 67 \\
I100 & 15.9 & 159 & 0.2 & 45 & 240 & 35 & 2.8 & 49 \\
I250 & 17.9 & 120 & 0.1 & 32 & 240 & 25 & 2.5 & 53 \\
I550 & 19.5 & 127 & 0.1 & 30 & 198 & 17 & 2.3 & 31 \\
I700 & 13.3 & 88 & 0.1 & 15 & 79 & 13 & 1.3 & 16 \\
\hline
\end{tabular}

\begin{tabular}{lrrrrrrrr}
\hline \multicolumn{1}{c}{ Site } & \multicolumn{1}{c}{ Pb } & \multicolumn{1}{c}{ Sr } & \multicolumn{1}{c}{ Th } & \multicolumn{1}{c}{ U } & \multicolumn{1}{c}{ V } & \multicolumn{1}{c}{ Zn } & Cu/Fe & Cd/Th \\
\hline Gulch basalt & 1.0 & 401 & 0.6 & 0.2 & 345 & 134 & 13.4 & 19.4 \\
Hillside basalt & 3.5 & 1,330 & 5.8 & 1.9 & 23 & 149 & 1.2 & 2.4 \\
Kawela mouth & 5.8 & 233 & 5.6 & 2.5 & 89 & 124 & 1.6 & 4.3 \\
Kawela br & 5.2 & 328 & 5.6 & 2.0 & 120 & 137 & 1.9 & 4.0 \\
Kawela confl & 5.0 & 296 & 5.6 & 2.1 & 229 & 183 & 2.1 & 4.5 \\
Kawela val & $* 49.8$ & 205 & 4.4 & 1.5 & 239 & 140 & $* 12.8$ & 5.1 \\
Kawela 2km & 5.4 & 305 & 4.9 & 2.3 & 108 & 137 & 1.9 & 4.7 \\
\hline Kamalo br1 & 6.2 & 425 & 5.9 & 1.7 & 211 & 143 & 5.8 & 3.4 \\
Kamalo br2 & 9.6 & 201 & 9.6 & 2.5 & 128 & 150 & 6.4 & 6.1 \\
Kamalo val & 8.7 & 230 & 9.3 & 2.4 & 128 & 148 & 3.4 & 4.6 \\
Kamalo 2km & 4.8 & 479 & 5.4 & 1.4 & 217 & 151 & 3.2 & 3.9 \\
A050 & 4.2 & 1,015 & 2.9 & 1.8 & 322 & 212 & 5.1 & 5.8 \\
A100 & 4.2 & 1,586 & 2.7 & 2.4 & 222 & 160 & 5.0 & 5.1 \\
A250 & 9.7 & 3,210 & 1.0 & 3.6 & 46 & 28 & 6.4 & 5.3 \\
A550 & 2.9 & 3,349 & 1.1 & 3.3 & 45 & 25 & 5.2 & 6.4 \\
A700 & 4.3 & 4,457 & 0.7 & 3.7 & 31 & 17 & 6.6 & 8.6 \\
\hline B050 & 4.8 & 1,674 & 4.8 & 2.6 & 160 & 190 & 2.0 & 3.2 \\
B400 & 1.6 & 4,403 & 1.1 & 4.1 & 47 & 34 & 3.3 & 7.8 \\
\hline C050 & 6.1 & 565 & 6.8 & 2.2 & 83 & 146 & 0.9 & 2.8 \\
C100 & 6.5 & 736 & 7.1 & 2.5 & 92 & 148 & 0.9 & 2.5 \\
C250 & 4.8 & 1,701 & 4.8 & 3.1 & 84 & 98 & 1.8 & 3.0 \\
C550 & 9.2 & 3,696 & 1.9 & 3.6 & 49 & 43 & 2.1 & 4.0 \\
C700 & 1.0 & 3,085 & 0.5 & 2.2 & 16 & 15 & 5.0 & 12.4 \\
\hline D050 & 5.4 & 783 & 6.3 & 2.3 & 112 & 150 & 1.0 & 3.0 \\
D400 & 6.3 & 1,692 & 3.9 & 2.7 & 62 & 63 & 1.8 & 2.7 \\
\hline & & & & & & & & \\
\hline
\end{tabular}




\section{Appendix 2 (cont'd).}

\begin{tabular}{|c|c|c|c|c|c|c|c|c|}
\hline Site & $\mathrm{Pb}$ & $\mathrm{Sr}$ & Th & U & V & $\mathrm{Zn}$ & $\mathrm{Cu} / \mathrm{Fe}$ & $\mathrm{Cd} / \mathrm{Th}$ \\
\hline E050 & 13.3 & 952 & 4.6 & 2.3 & 197 & 199 & 1.6 & 3.9 \\
\hline E100 & 5.3 & 593 & 5.5 & 2.3 & 233 & 186 & 1.5 & 3.4 \\
\hline E250 & 6.4 & 486 & 4.3 & 1.8 & 517 & 326 & 0.7 & 5.0 \\
\hline E400 & 4.7 & 2,690 & 2.5 & 2.3 & 157 & 96 & 2.2 & 4.0 \\
\hline E550 & 4.6 & 1,284 & 4.8 & 2.5 & 127 & 105 & 1.6 & 2.9 \\
\hline E700 & 3.6 & 1,638 & 2.7 & 1.8 & 62 & 51 & 2.8 & 2.7 \\
\hline G050 & 3.2 & 807 & 3.2 & 1.6 & 134 & 117 & 1.3 & 3.4 \\
\hline G100 & 3.8 & 1,239 & 4.0 & 2.4 & 182 & 144 & 2.2 & 3.4 \\
\hline G250 & 3.4 & 1,887 & 2.7 & 2.5 & 214 & 144 & 1.2 & 4.2 \\
\hline G400 & 2.6 & 2,282 & 2.9 & 2.7 & 165 & 115 & 1.2 & 4.1 \\
\hline G550 & 2.8 & 1,687 & 2.1 & 2.1 & 70 & 50 & 1.4 & 3.9 \\
\hline H050 & 7.3 & 1,139 & 4.0 & 2.1 & 247 & 187 & 1.5 & 3.8 \\
\hline H100 & 2.8 & 1,923 & 2.6 & 2.4 & 257 & 172 & 1.4 & 4.8 \\
\hline $\mathrm{H} 250$ & 4.4 & 1,989 & 2.3 & 2.2 & 151 & 102 & 1.3 & 3.7 \\
\hline H550 & 3.3 & 2,270 & 1.4 & 1.6 & 59 & 42 & 2.1 & 3.4 \\
\hline $\mathrm{H} 700$ & 2.3 & 2,578 & 1.4 & 1.9 & 41 & 27 & 2.2 & 4.0 \\
\hline $\mathrm{I} 050$ & 5.0 & 1,183 & 3.5 & 1.9 & 402 & 217 & 2.5 & 4.7 \\
\hline I100 & 3.6 & 1,058 & 3.2 & 1.9 & 430 & 259 & 1.8 & 4.8 \\
\hline $\mathrm{I} 250$ & 7.9 & 2,446 & 2.2 & 2.3 & 322 & 198 & 1.7 & 5.4 \\
\hline I550 & 2.1 & 4,402 & 2.2 & 3.7 & 305 & 180 & 1.3 & 5.6 \\
\hline I700 & 1.6 & 3,490 & 1.6 & 2.5 & 158 & 93 & 1.7 & 4.6 \\
\hline
\end{tabular}

